mind since he wrote on leprosy in Japan, explain how the disease arises from a depravity of digestion, caused by the excessive absorption of rice. He, I suppose, is one of the renowned leprologists whose works are knoun to Dr. Ehlers, and it is to be hoped, for the amusement of all the scientists who will meet in Berlin, that there are still other men living who possess no less imagination than Dr. Wernich.

We do not care very much about the greater or less renown of a leprologist; this is absolutely of no account in our business. We might say that Dr. Hansen is the greatest of leprologists, because be chanced to light on the bacillus. Yet the discovery of the bacillus has not saved one human being, has not diminished the sufferings of a human creature. If a thousand leprologists, as great as Hansen, meet, they will not do more than Hansen himself has been able to do. Not any of the know' $n$ works of the learned gentlemen can do more than the discoverer of the bacillus has been able to do. All that the greatest of leprologists has been able to do, was done by isolation, imposed by his own government, and independently of the bacillus, and uithout palaver.

Albert S. A shmead, M.D.

P. S. In a letter dated Nov. 16, 1896, to Dr. Goldschmidt of Paris, Dr. Ehlers, the Secretary of the Berlin Leprosy Conference Committee, said "that he could assure him that Dr. Hansen had never approved the project of Dr. Ashmead, and that the latter acted without any kind of authority from the Norwegian government, and even without the formal authorization of Dr. Hansen."

In a letter to me dated Sept. 4, 1896, Dr. Hansen says: "I should best like if you and Dr. Goldschmidt alone took the task of convoking the Congress on your shoulders; but should you think it very desirable to have my name, you may use it, but on the condition that the Congress is only regarded as arranged by us. If the Congress then will meet in Bergen, I hope still that the Norwegian government will pay the business matters; the best would be, if the participating governments each paid their tribute.

"If the Congress shall not be secured without its help, the government will probably ask a credit to furnish the Congress with a secretary, local (place), for the meetings, and other matters of business.'

This shows conclusively, I think, that Dr. Hansen permitted the use of his name on our provisional committee, and gave us warrant to use the name of his government.

Albert S. Ashmead, M.D.

\section{"Independent Medical College" Mill.}

Tecumseh, Mrch., Jan. 8, 1897.

To the Editor:-I inclose you what purports to be a medical journal. It certainly is the rankest thing I ever saw. Is it not likely that it is the child of the Wisconsin Eclectic Medical College? You will notice that the editor is J. Armstong of Chicago. I have looked him up in Polk's Medical and Surgical Register of the United States, 1896, and find that he lives at $683 \mathrm{~W}$. Van Buren St., but following his name is the little star that refers to the following note at the bottom of the page : "No report received in answer to inquiry regarding graduation." J. H. Randall, Ph.D., M.D., is given as associate editor, but his name does not appear at all in Polk's Register and I mistrust he is a myth. I am lead to this belief by comparing the name, with those given on page 14 in the article, "Report of Proceedings of the United States Medical Liberty League." It is stated that several persons met to organize the league in response to invitations of the faculty of the Independent Medical College, and in the proceedings the names of five M.Ds., are given, namely : J. Armstrong, Mary E. Sellen, C. K. Drumheller, A. J. Clausen, J. H. Randall. The first two are given in Polk's Register. Mary E. Sellen is or was a resident of Columbus, Ohio, and her school of practice is given as "Sci.," if any one knows what that is. The names of the other three organizers of the United States Medical Liberty League can not be found in Polk's Register anywhere in the United States.
I have no doubt that J. Armstrong and Mary E. Sellen are the prime movers and that they are the officers and members of the league. On the last page of cover is an advertisement of the Independent Medical College, which announces that "This school advocates a new and successful method of acquiring a medical education." The names of the members of the faculty are not given if there are any, but as the announcement is the baldest possible bid for the sale of diplomas without college attendance, and as the journal is avowedly opposed to all medical legislation, it is almost certain that J. Armstrong and Mary E. Sellen are "the journal," the league and the college, all in two. On page 16 are the opinions of doctors who have read No. 1 of the Medical Liberty Neus (this copy is No. 2 ) and have words of commendation for it. There are just six of them, and three of them have the suspicious and tell-tale star following their names in Polk's Register, and the names of the other three do not appear at all. The object of the "Tiberty league" seems to be to organize and raise funds to oppose all medical legislation and in case any member of the league is prosecuted for illegal practice to help him with funds and prestige. On page -- occurs this fine statement: "We also declare persisent and uncompromising warfare against the practice of vivisecting live animals."

I send the pamphlet to you in the hope that you will put it in to the hands of the proper officials and that they can by legal means shut up the "diploma mill" at least. Their journal and the "league" are beyond the reach of the law, I fear.

I am very respectfully yours,

L. G. North.

\section{Massage.}

Chicago, Ill., Feb. 15, 1897.

To the Editor:-In the Journal, issue of Jan. 9, 1897, there appeared a part of a serial article on "Massage," written by myself, which was "to be continued." As the continuation did not appear, I wrote to you about February 12 inquiring the reason thereof and received from you the following reply:

"Dear Doctor:--I have your letter of February and have to say that after publishing the first part of your article we had a protest from Dr. Douglas Graham, in which he claimed that a large portion of the history of massage was taken from his book, a charge which seems to be sustained, etc."

1. Now, as a matter of fact, I did quote Dr. Douglas Graham some and wherever I did I think I gave him credit for it. I did not put his name at the end of each line, but at the end of certain articles. If $I$ should have neglected to do this in any instance it was an oversight and I beg pardon of Dr. Graham.

2. I challenge Dr. Graham to prove that the "Ancient History of Massage" as I have written it is entirely original with him, and I will prove to him that there are a score of books on the subject by other authors who use language similar or like it in part. Dr. Graham can not quote ancient history and call it his own.

3. Get a number of books on any subject (medical), as surgery, for instance, and does not one author quote the other or a dozen others?

4. I do not know as I quoted Dr. Graham any more than other authors; if I did, then he ought to be proud of it.

Since when is medical literature private property? Respectfully yours, JOHN KERCHER, M.D.

\section{Embryonic Specimens Wanted.}

\section{Baltimore, Md., Feb. 20, 1897.}

To the Editor:-During the last ten years I have appealed to physicians from time to time to send me the human embryos which fell into their hands, and have in this way procured some very valuable specimens. These specimens have been cut into sections, and are now being modeled and studied very carefully. Yet a number of important stages are still wanting, and I therefore ask through your columns that physicians send me any material which they may obtain.

The best method to preserve human ova is to place the unopened ovum, without handling, and as soon as possible, in strong alcohol. By this method the embryo within is well hardened for future microscopic study. 